\title{
RESULT OF THE ARC OF MOVEMENT OF LOWER CERVICAL SPINE AFTER SEVEN YEARS OF ARTHROPLASTY
}

\author{
RESULTADO DO ARCO DE MOVIMENTO DA COLUNA CERVICAL BAIXA DEPOIS DE SETE \\ ANOS DE ARTROPLASTIA
}

\section{RESULTADO DEL ARCO DE MOVIMIENTO DE LA COLUMNA CERVICAL BAJA DESPUÉS DE SIETE AÑOS DE ARTROPLASTIA}

Luis Claudio de Velleca e Lima ${ }^{1,2}$, Fernando Gritsch Sanchis ${ }^{1,2}$

\begin{abstract}
Objective: To quantify the mobility of the lower cervical spine after seven years of total cervical disc replacement at two levels. Method: This clinical study was designed randomly and prospectively at the spine surgery center at the Hospital Nossa Senhora das Graças, in Canoas, RS-Brazil and at the Hospital Don João Becker, in Gravataí, RS-Brazil. Seventeen patients were included in the study that was designed to compare the data obtained from annual and sequential manner until the end of seven years. A comparison was made with the prior range of motion (ROM) of each patient. All patients were diagnosed with not tractable symptomatic cervical degenerative disc disease with two adjacent levels between C-3 and C-7. Results: A total of patients underwent TDR in two levels and at the end of seven years, only one patient was lost to follow-up. The pre and postoperative ROM was the same in the first three years however after the fourth year there was a gradual decline with a loss of $12 \%$ of preoperative ROM in flexion, $21 \%$ in extension and $23 \%$ in the right and left lateral bending at the end of seven years. Conclusions: The clinical outcome of this study is evidence level IV in evaluating the ROM for Moby-C ${ }^{\circledR}$ for TDR in two adjacent levels at the lower cervical spine. These results show that the ROM is maintained during the first three years, gradually declining after that.
\end{abstract}

Keywords: Arthroplasty; Intervertebral disc; Intervertebral disc degeneration.

\begin{abstract}
RESUMO
Objetivo: Quantificar a mobilidade da coluna cervical baixa após sete anos de artroplastia de disco cervical em dois níveis. Método: 0 ensaio clínico foi elaborado de maneira aleatória e prospectiva nos centros de cirurgia da coluna vertebral no Hospital Nossa Senhora das Graças em Canoas, RS, Brasil e no Hospital Don João Becker, em Gravataí, RS, Brasil. Dezessete pacientes foram submetidos ao estudo que foi delineado seguindo a comparação dos dados obtidos de maneira sequencial e anual até o final dos sete anos. A comparação foi feita com o arco de movimento (ADM) pré-operatório de cada paciente. Todos os pacientes foram diagnosticados com doença cervical degenerativa sintomática e não tratável, com dois níveis contíguos entre C-3 e C-7. Resultados: Todos os pacientes receberam o procedimento de $A D C$ para dois níveis sendo que ao final dos sete anos, apenas um paciente não terminou o acompanhamento. O ADM pré e pós-operatório manteve-se inalterado nos primeiros 3 anos, mas após o quarto ano houve declínio gradual com perda de 12\% do ADM pré-operatório em flexão, $21 \%$ em extensão e $23 \%$ em inclinação lateral direita e esquerda ao cabo de sete anos. Conclusões: 0 resultado clínico desse estudo representa nível de evidência IV na avaliação de ADM para ADC em dois níveis contíguos, utilizando o Mobi-C ${ }^{\circledR}$ na coluna cervical baixa. Esses resultados evidenciam que o ADM apresenta manutenção pré-operatória nos primeiros três anos, declinando gradualmente através dos anos.
\end{abstract}

Descritores: Artroplastia; Disco intervertebral; Degeneração do disco intervertebral.

\section{RESUMEN}

Objetivo: Cuantificar la movilidad de la columna cervical baja después de siete años de artroplastia de disco cervical en dos niveles. Método: El ensayo clínico fue elaborado de manera aleatoria y prospectiva en los centros de cirugía de la columna vertebral en el Hospital Nossa Senhora das Graças en Canoas, RS, Brasil y en el Hospital Don João Becker, en Gravataí; RS-Brasil. Diecisiete pacientes fueron sometidos al estudio que fue delineado siguiendo la comparación de los datos obtenidos de manera secuencial y anual hasta el fin de los siete años. La comparación fue hecha con el arco de movimiento (ADM) preoperatorio de cada paciente. Todos los pacientes fueron diagnosticados con enfermedad cervical degenerativa sintomática y no tratable, con dos niveles contiguos entre C-3 y C-7. Resultados: Todos los pacientes recibieron el procedimiento de ADC para dos niveles siendo que al fin de los siete años, solamente un paciente no terminó el acompañamiento. El ADM pre y postoperatorio se mantuvo inalterado en los primeros 3 años, pero después del cuarto año hubo disminución gradual con pérdida de 12\% del ADM preoperatorio en flexión, 21\% en extensión y 23\% en inclinación lateral derecha e izquierda al cabo de siete años. Conclusiones: El resultado clínico de este estudio representa nivel de evidencia IV en la evaluación de ADM para ADC en dos niveles contiguos, utilizando Mobi-C ${ }^{\circledR}$ en la columna cervical baja. Estos resultados evidencian que el ADM presenta mantenimiento preoperatorio en los primeros tres años, declinando gradualmente a través de los años.

Descriptores: Artroplastia; Disco intervertebral; Degeneración del disco intervertebral.

1. Hospital Nossa Senhora das Graças, Canoas, RS, Brazil.

2. Hospital Dom João Becker, Gravataí, RS, Brazil.

Study conducted at the Hospital Dom João Becker and Hospital Nossa Senhora das Graças, RS, Brazil.

Correspondence: Rua Costa, 217, apto. 207. Menino Deus, Porto Alegre, RS, Brasil. 90110-270 Icvelleca@gmail.com/lcvelleca@yahoo.com 


\section{INTRODUCTION}

Cervical disc arthroplasty (CDA) was developed to treat the symptoms of degenerative disease of the cervical intervertebral discs, and began to be widely used in 1990 as an alternative to anterior approach discectomies with intersomatic fusion. ${ }^{1-4}$ The advantage offered by CDA was that it maintained the range of motion (ROM) of the spine in combination with the treatment of pain and nerve-related symptoms of the degenerative disease of the cervical spine. ${ }^{4,5}$ Using CDA preserves the spinal biomechanics and integrity of the adjacent levels, while intersomatic fusion imposes new biomechanics on the spine that restrict the ROM of the treated levels, leading to hypermobility of the adjacent levels by increasing intradisc pressure. This configuration can cause recurrent symptoms in $25 \%$ of patients. ${ }^{4-6}$ Since 2007 there has been significant diffusion of CDA with equivalence between the final results of anterior approach intersomatic fusion and CDA of a single level. In 2013, a comparison between intersomatic fusion and CDA of two levels showed evidence of superiority in the short term. ${ }^{7-10}$ The purpose of this study is the evaluate the evolution of the range of motion of the lower cervical spine seven years following CDA of two levels in the lower cervical spine.

\section{METHODS}

The Mobi-C $\AA$ prosthesis was used as the instrument for the CDA. The prosthesis consists of two chrome-cobalt-molybdenum end plates with a low profile artificial disc made of ultra-low molecular weight polyethylene. The bone contact surfaces are coated with a low profile titanium and hydroxyapatite spray. The ROM advertised by the manufacturer of the Mobi- $C^{\circledR}$ prosthesis (LDR Holding Corporation, USA) includes five distinct types of movement: two of translation and three of rotation. (Figure 1) The prosthesis is designed to be used in multiple levels, without the need for screws or other fixation materials that would prevent the accommodation of another implant in the upper or lower level.

This was a prospective study, with follow-up of 17 patients who underwent surgery in the spine surgery center of the Hospital Dom João Becker and Hospital Nossa Senhora das Graças, RS, Brazil. All the patients who were diagnosed with cervical degenerative disease in two contiguous levels of the lower cervical spine (C3-C7) between April 2006 and April 2007, and who did not have success with at least two weeks of conservative treatment, were included in the study. The inclusion and exclusion criteria are shown in Table 1. The data were analyzed using the EPIINFO 3.4.1 program.

The Smith-Robinson approach for anterior cervical spine was the surgical technique used for decompression of the nerve structures and implantation of the disc prosthesis. A drain was not used postoperatively, and rehabilitation began one week following the surgery with continuously progressive exercises to maintain the ROM. The

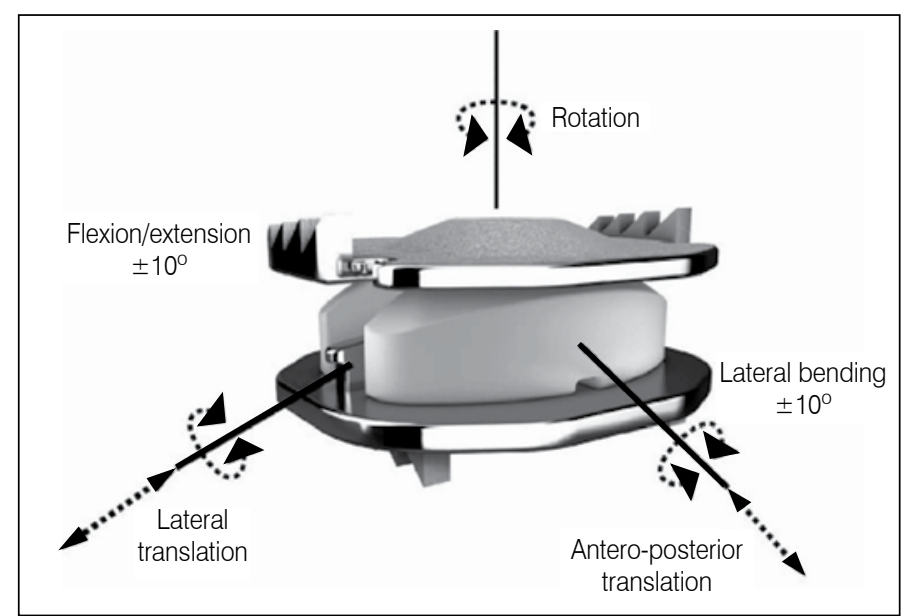

Figure 1. $\mathrm{MOBI}-\mathrm{C}^{\circledR}$ prosthesis.
Table 1. Inclusion and exclusion criteria.

\section{Inclusion criteria}

1. Age between 18 and 65 years;

2. Cervical degenerative disease between $\mathrm{C} 3-\mathrm{C} 7$ with two contiguous levels with:

a) Cervical and/or arm pain and/or;

b) Reduced strength in the arm and/or;

c) Change in sensitivity and/or;

d) Change in reflex.

3. Diagnosis confirmed by MRI;

4. Lack of success from a minimum of six weeks of conservative treatment or signs of evolution of symptoms of neurological compression at the central or peripheral level, despite conservative treatment;

5. No previous surgical treatment of the levels to be approached and no intersomatic fusion procedure at any level of the spine;

6. Having signed the informed consent form.

\section{Exclusion criteria}

1. More than 2 levels requiring surgical treatment;

2. Thickness of the disc less than $3 \mathrm{~mm}$;

3. T score lower than 1.5 after adjustment for age;

4. Presence of metabolic disease;

5. Presence of cancer without at least five years declared free of cancer by the Oncology Group;

6. Cervical instability in the radiographical lateral bending, flexion, and extension stress exams;

7. Allergies to chrome, cobalt, or molybdenum;

8. Segmentary angulation more than 11 degrees in the levels in question or the adjacent levels;

9. BMl greater than 40 ;

10. Tobacco users who smoke more than one pack of cigarettes a day;

11. Presence of mental illness.

use of non-steroidal anti-inflammatories was discontinued one week after surgery and resumed only after three months if extremely necessary, in order to prevent heterotopic ossification.

The patients were monitored weekly during the first month, monthly for the first six months, every six months during the first two years, and then once a year. The ROM was measured three times during the first year $(1,6$, and 12 months) and then once a year.

\section{RESULTS}

Of the 17 patients who underwent the protocol, only one was lost to follow-up over seven years. There were no new surgical procedures in any of the patients, and one patient was treated for 30 days with oral antibiotics for a soft tissue infection without recurrence. The demographic profile of the patients is shown in Table 2.

The evolution of the range of motion of the respective patients is shown in Table 3 and the data summary is shown in Figure 2. It can be seen that there was a loss of $12 \%$ of the preoperative ROM in flexion, $21 \%$ in extension, and $23 \%$ in right and left lateral bending of the lower cervical spine in the seventh postoperative year.

Table 2. Patient demographic data.

\begin{tabular}{c|c}
\hline Demographic measurement & $\mathbf{N}=\mathbf{1 6}$ \\
\hline Sex M/F & $\mathbf{7 / 9}$ \\
\hline Age (years) & 52.9 \\
\hline BMl & 25.4 \\
\hline Able to work & 7 \\
\hline
\end{tabular}


Table 3. Range of motion by patient by year.

\begin{tabular}{|c|c|c|c|c|c|c|c|c|}
\hline Patient & Preop * & Year 1 & Year 2 & Year 3 & Year 4 & Year 5 & Year 6 & Year 7 \\
\hline \multirow{4}{*}{1} & F: 40 & $F: 40$ & $F: 35$ & $F: 35$ & $F: 35$ & $F: 35$ & $F: 30$ & $F: 30$ \\
\hline & E: 50 & E: 45 & E: 50 & E: 50 & E: 50 & $E: 45$ & E: 40 & E: 35 \\
\hline & R: 30 & R: 20 & R: 25 & R: 25 & R: 25 & R: 25 & R: 25 & R: 25 \\
\hline & $L: 30$ & L: 20 & L: 25 & L: 25 & L: 25 & L: 25 & L: 25 & L: 25 \\
\hline \multirow{4}{*}{2} & F: 45 & F: 40 & F: 40 & F: 40 & F: 40 & F: 35 & F: 40 & F: 40 \\
\hline & E: 45 & E: 40 & E: 40 & E: 40 & E: 40 & E: 30 & E: 35 & E: 35 \\
\hline & R: 35 & R: 35 & R: 35 & R: 35 & R: 35 & R: 35 & R: 35 & R: 35 \\
\hline & L: 35 & L: 35 & L: 35 & L: 35 & $L \cdot 35$ & L. 35 & $L \cdot 35$ & L. 35 \\
\hline \multirow{4}{*}{3} & F: 35 & F: 40 & F: 40 & F: 35 & F: 35 & F: 30 & F: 30 & $F: 30$ \\
\hline & E: 40 & E: 40 & E: 40 & E: 35 & E: 35 & E: 35 & E: 35 & E: 30 \\
\hline & R: 30 & R. 30 & R: 25 & R: 25 & R: 25 & R: 25 & R: 25 & R: 20 \\
\hline & L: 30 & L: 30 & L: 25 & L: 25 & L: 25 & L: 25 & L: 25 & L: 20 \\
\hline \multirow{4}{*}{4} & F: 40 & F: 40 & $F: 40$ & $F: 40$ & F: 40 & F: 35 & F: 35 & F 35: \\
\hline & E: 50 & E: 50 & E: 50 & E: 50 & E: 50 & E: 45 & E: 45 & E: 45 \\
\hline & R: 30 & R: 30 & R: 30 & R: 30 & R: 30 & R: 25 & R: 25 & R: 25 \\
\hline & L: 30 & L: 30 & L: 30 & L: 30 & L: 30 & L: 25 & L: 25 & L: 25 \\
\hline \multirow{4}{*}{5} & F: 35 & F: 40 & F: 40 & F: 40 & F: 35 & F: 35 & F: 35 & $F: 35$ \\
\hline & E: 40 & $E: 40$ & E: 40 & E: 40 & E: 35 & E: 35 & $E: 30$ & E: 30 \\
\hline & R: 20 & R: 40 & R: 40 & R: 40 & R: 30 & R: 30 & R: 30 & R: 30 \\
\hline & L: 20 & L: 40 & L: 40 & L: 40 & L: 30 & L: 30 & $L: 30$ & $L: 30$ \\
\hline \multirow{4}{*}{6} & F: 35 & $F: 40$ & $F: 40$ & F: 35 & F: 35 & F: 30 & $F: 30$ & $F: 30$ \\
\hline & E: 40 & E: 40 & E: 40 & E: 35 & E: 35 & E: 35 & E: 35 & E: 30 \\
\hline & R: 30 & R: 30 & R: 25 & R: 25 & R: 25 & R: 25 & R: 25 & R: 20 \\
\hline & L. 30 & $\frac{n .50}{L: 30}$ & $\frac{n}{L: 25}$ & $\frac{\text { n. }}{L: 25}$ & $\frac{1.20}{L: 25}$ & $\frac{1.20}{L: 25}$ & $\frac{1.20}{L: 25}$ & L. 20 \\
\hline \multirow{4}{*}{7} & F: 40 & F: 40 & F: 35 & F: 35 & F: 35 & F: 35 & F: 30 & $F: 30$ \\
\hline & E:50 & E: 45 & E: 50 & E: 50 & E: 50 & $E: 45$ & E: 40 & E: 35 \\
\hline & R: 30 & R: 20 & R: 25 & R: 25 & R: 25 & R: 25 & R: 25 & R: 25 \\
\hline & $L \cdot 30$ & $L: 20$ & L. 25 & L. 25 & L. 25 & $L: 25$ & $L: 25$ & L. 25 \\
\hline \multirow{4}{*}{8} & $F: 35$ & $F: 40$ & $F: 40$ & F: 35 & F: 35 & $F: 30$ & $F: 30$ & $F: 30$ \\
\hline & $E: 40$ & E: 40 & E: 40 & E: 35 & E: 35 & E: 35 & F. 35 & E. 30 \\
\hline & R: 30 & R: 30 & $\begin{array}{l}\text { R. } 25 \\
\text { R: }\end{array}$ & R: 25 & R: 25 & R: 25 & R: 25 & R: 20 \\
\hline & L: 30 & L: 30 & L: 25 & L: 25 & $L: 25$ & $L: 25$ & $L: 25$ & L: 20 \\
\hline \multirow{4}{*}{9} & $F: 35$ & F: 40 & $F: 40$ & F: 35 & F: 35 & $\mathrm{~F}: 30$ & F: 30 & F: 30 \\
\hline & E. 40 & E. 40 & E. 40 & E. 35 & E. 35 & F. 35 & F. 35 & E. 30 \\
\hline & R: 30 & R: 30 & R: 25 & R: 25 & R: 25 & R: 25 & R: 25 & R: 20 \\
\hline & L: 30 & $L: 30$ & L: 25 & L: 25 & L: 25 & $L: 25$ & $L: 25$ & L: 20 \\
\hline \multirow{4}{*}{10} & F: 40 & F: 40 & F: 40 & F: 40 & F: 40 & F: 35 & F: 35 & F $35:$ \\
\hline & E: 50 & E: 50 & E: 50 & E: 50 & E: 50 & E: 45 & E: 45 & E: 45 \\
\hline & R: 30 & R: 30 & R: 30 & R: 30 & R: 30 & R: 25 & R: 25 & R: 25 \\
\hline & L: 30 & L: 30 & L: 30 & L: 30 & L: 30 & $L: 25$ & L. 25 & L: 25 \\
\hline & $F: 35$ & F: 40 & F: 40 & F: 35 & F: 35 & $F: 30$ & F: 30 & $F: 30$ \\
\hline 1 & E: 40 & E: 40 & E: 40 & E: 35 & E: 35 & E: 35 & E: 35 & E: 30 \\
\hline 11 & R: 30 & R: 30 & R: 25 & R: 25 & R: 25 & R: 25 & R: 25 & R: 20 \\
\hline & L. 30 & L. 30 & L: 25 & n. 25 & n. 25 & L: 25 & L. 25 & L. 20 \\
\hline & $\mathrm{F}: 40$ & F: 40 & F: 40 & F: 40 & F: 40 & F: 35 & F: 35 & F 35: \\
\hline & E: 50 & E. 50 & E. 50 & E. 50 & E. 50 & E: 45 & E: 45 & E: 45 \\
\hline 12 & R: 30 & R: 30 & R: 30 & R: 30 & R. 30 & R. 25 & R. 25 & $\frac{1.45}{\text { R. } 25}$ \\
\hline & L: 30 & L: 30 & L: 30 & L: 30 & L: 30 & L:25 & L: 25 & L: 25 \\
\hline & F: 35 & $F: 40$ & F: 40 & $F: 35$ & F: 35 & F: 30 & F: 30 & $F: 30$ \\
\hline 12 & E: 40 & E: 40 & E: 40 & E: 35 & E: 35 & E. 35 & E. 35 & E: 30 \\
\hline 13 & R: 30 & R. 30 & R: 25 & R: 25 & R: 25 & R. 25 & R: 25 & R: 20 \\
\hline & L: 30 & L: 30 & L: 25 & L: 25 & L: 25 & L: 25 & L: 25 & L: 20 \\
\hline & F: 35 & F: 40 & F: 40 & F: 40 & F: 35 & F: 35 & F: 35 & F: 35 \\
\hline 11 & E: 40 & E: 40 & E: 40 & $E: 40$ & E. 35 & E: 35 & E. 30 & E. 30 \\
\hline 14 & R: 20 & R: 40 & R: 40 & R. 40 & R. 30 & R: 30 & R: 30 & R. 30 \\
\hline & L: 20 & L: 40 & L: 40 & L: 40 & L: 30 & L: 30 & L: 30 & L: 30 \\
\hline & F: 40 & F. 40 & F. 40 & F. 40 & F: 40 & F: 35 & F. 35 & F 35 . \\
\hline & E: 50 & E: 50 & E: 50 & E: 50 & E. 50 & E: 45 & E: 45 & E: 45 \\
\hline 15 & R: 30 & R: 30 & R: 30 & R: 30 & R: 30 & R: 25 & R: 25 & R: 25 \\
\hline & $\frac{10.50}{L} \cdot 30$ & L. 30 & $\frac{\text { n. }}{L .30}$ & $\frac{\text { n. } 00}{L .30}$ & $\frac{n .50}{L .30}$ & n. 25 & 17. 25 & $\frac{10.25}{L .25}$ \\
\hline & F: 40 & $F: 40$ & F: 40 & F: 40 & F: 40 & $F: 35$ & $F: 35$ & F 35: \\
\hline & E: 50 & E: 50 & E: 50 & E: 50 & E: 50 & E: 45 & E: 45 & E: 45 \\
\hline 16 & R. 30 & R: 30 & R: 30 & R: 30 & R. 30 & $\begin{array}{l}\text { L. } 45 \\
\text { R. } 25\end{array}$ & R. 25 & R. 25 \\
\hline & L. 30 & $L \cdot 30$ & L. 30 & 1.30 & L. 30 & L. 25 & L. 25 & L. 25 \\
\hline & $F: 37,8$ & F: 40 & $F: 39,4$ & F: 37,5 & $F: 36,9$ & $F: 32,8$ & F: 32,8 & $F: 32,8$ \\
\hline & E: 44.7 & $E: 43.8$ & $E: 44,4$ & E: 42,5 & F. 419 & E. 39,1 & E. 381 & E. 356 \\
\hline Média & R. 29.1 & $\begin{array}{l}\text { R: } 29,0 \\
\text { R: }\end{array}$ & R. 29.4 & R: 29.1 & $\begin{array}{l}\text { R. } 41,5 \\
\text { R: } 27.8\end{array}$ & $\begin{array}{l}\text { L. } \\
\text { R: } 21.6\end{array}$ & $\begin{array}{l}\text { L. } 00,1 \\
\text { R: } 26,3\end{array}$ & R:22, \\
\hline & 1.291 & $\frac{1.20 .1}{1.303}$ & $\frac{1.20 .4}{1.281}$ & $\frac{1.20,1}{1.306}$ & $\frac{1.270}{1.278}$ & $\frac{1.21,0}{1.266}$ & $\frac{11.20,0}{1.263}$ & $\frac{1.22,4}{1.24 .4}$ \\
\hline
\end{tabular}

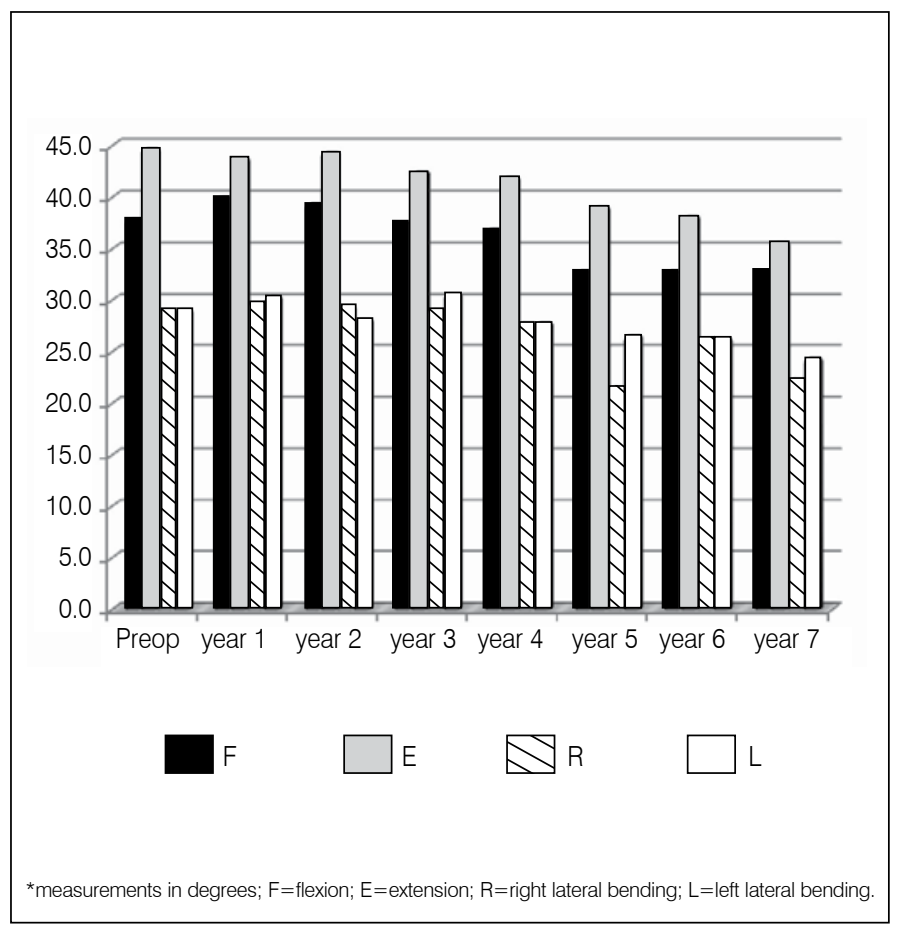

Figure 2. General range of motion by year.

\section{DISCUSSION}

Over the last ten years, there has been level I evidence to support the superiority of CDA of one level when compared to single-level intersomatic fusion. The big advantage is in the conservation of the spinal ROM and consequently the spinal biomechanics, which reduces the overload on the adjacent level and results in a lower rate of recurring symptoms. ${ }^{2-5,10}$ This study may show that despite the reduction in the ROM seven years after CDA of two contiguous levels of the lower cervical spine, at least $75 \%$ of the initial ROM is maintained.

\section{CONCLUSION}

The study demonstrates that the ROM of the cervical spine decreases during the years following CDA of two contiguous levels of the lower cervical spine by $12 \%$ in flexion, $21 \%$ in extension, and $23 \%$ in right and left lateral bending. These values were derived through prospective analysis, generating a grade IV evidence level for maintenance of the ROM after CDA of two levels.

All authors declare no potential conflict of interest concerning this article.

\section{REFERENCES}

1. Smith GW, Robinson RA. The treatment of certain cervical-spine disorders by anterior removal of the intervertebral disc and interbody fusion. J Bone Joint Surg Am. 1958;40(3):607-24.

2. Pracyk JB, Traynelis VC. Treatment of the painful motion segment: cervical arthroplasty. Spine (Phila Pa 1976). 2005;30(Suppl 16):S23-32

3. Anderson PA, Rouleau JP. Intervertebral disc arthroplasty. Spine (Phila Pa 1976). 2004:29(23):2779-86

4. Dmitriev AE, Cunningham BW, Hu N, Sell G, Vigna F, McAfee PC. Adjacent level intradiscal pressure and segmental kinematics following a cervical total disc arthroplasty: an in vitro human cadaveric model. Spine (Phila Pa 1976). 2005:30(10):1165-72.

5. Hilibrand AS, Robbins M. Adjacent segment degeneration and adjacent segment disease: the consequences of spinal fusion? Spine J. 2004;4(Suppl 6):190S-4

6. Robertson JT, Papadopoulos SM, Traynelis VC. Assessment of adjacent-segment disease in patients treated with cervical fusion or arthroplasty: a prospective 2-year study. J Neurosurg Spine. 2005;3(6):417-23.

7. Davis RJ, Araghi A, Bae HW, Hisey MS, Nunley PD: Comparison of complication rates associated with two level cervical arthroplasty versus two level anterior cervical discectomy and fusion. Spine J. 2012;12(9):139-40. Disponível em: http://www.thespinejournalonline. com/article/S1529-9430\%2812\%2900928-X/abstract

8. Heller JG, Sasso RC, Papadopoulos SM, Anderson PA, Fessler RG, Hacker RJ, et al. Comparison of BRYAN cervical disc arthroplasty with anterior cervical decompression and fusion: clinical and radiographic results of a randomized, controlled, clinical trial. Spine (Phila Pa 1976). 2009;34(2):101-7.

9. Mummaneni PV, Burkus JK, Haid RW, Traynelis VC, Zdeblick TA. Clinical and radiographic analysis of cervical disc arthroplasty compared with allograft fusion: a randomized controlled clinical trial. J Neurosurg Spine. 2007;6(3):198-209.

10. Davis RJ, Kim KD, Hisey MS, Hoffman GA, Bae HW, Gaede SE, et al. Cervical total disc replacement with the Mobi-C cervical artificial disc compared with anterior discectomy and fusion for treatment of 2-level symptomatic degenerative disc disease: a prospective, randomized, controlled multicenter clinical trial: clinical article. J Neurosurg Spine. 2013;19(5):532-45. 